\title{
Identifying factors causing cost overrun of the construction projects in India
}

\author{
SWAPNIL P WANJARI* and GAURAV DOBARIYA \\ Department of Civil Engineering, Visvesvaraya National Institute of Technology, Nagpur 440010, India \\ e-mail: swapnil_wanjari@yahoo.co.in; er.dobariyagaurav@gmail.com
}

MS received 1 June 2015; revised 14 January 2016; accepted 20 January 2016

\begin{abstract}
Delay and cost overrun are common phenomena in projects worldwide. However, these are especially severe in developing countries. In India as per MOSPI report, 235 projects out of 410 were severely affected cost overrun due to certain factors. A short questionnaire was conducted with 15 prominent factors responsible for cost overrun and forwarded to 190 constructional professionals across India. Total 85 responses were received and it was analyzed using various statistical tools such as analysis of variance (ANOVA) and factor analysis tool using SPSS. In this study, top three factors affecting cost overruns were identified such as price escalation of raw material, delay in planned activity and lack of co-ordination between construction parties which could be significantly responsible for cost overnun of construction project in India. Factor analysis method was also carried out to group the factors into three components of overall questionnaire. These components, such as client control component, project management component, and contractor control component, would be useful to the various parties involved in the construction activities. This paper also provides suggestive frameworks which have been framed after discussing with large number of construction professionals or expert.
\end{abstract}

Keywords. Cost overrun in India; ANOVA; factor analysis; construction projects.

\section{Introduction}

Cost overrun can be simply defined as "when the final cost of the project exceeds the original estimates" [1]. As per the 342nd Report of the Ministry of Statistics and Programme Implementation in India [2], projects of public sector in India are seriously affected by cost overruns due to various reasons. Four-hundred ten projects were reviewed out of 727 running projects all over India. It was found that 235 projects running were with cost overruns out of 410 projects. It was around $57 \%$ projects which has quite large and serious indication towards remedial measures. Delay and cost increase are common phenomena in projects worldwide. However, these are especially severe in developing countries [3]. MOSPI fact finding reports indicating $57 \%$ project causes cost overrun, on the other hand has also set an ambitious target of investing US \$1 trillion investments in infrastructure during the 2014-19 [4]. In order to meet requirements of developing in infrastructure in India, annual spending on infrastructure need to be more than double by year 2020 [4]. A very few studies were done in India on cost overrun of construction project; however, studies did not target entire view of India or high valued project cost, etc.

*For correspondence

\section{Literature review}

Many researchers have exercised cost overrun in their country through questionnaire survey or through interviewed with expert industries personal. Large numbers of factors which could be responsible for cost overrun. Some of the factors such as price escalation of raw materials [5-8], high cost of labour is shown in table 1 , such as price escalation, dispute in bill settlements, $[7,9,10]$, delayed in planned activity [6, 11, 12], etc. Around 25 numbers of factors were identified and summarized in table 1 along with references details. Since 25 numbers of factors are too large and some of factors have same meaning. These 25 numbers of factors were reduced to 15 numbers prominent factors responsible for cost overrun. Some of the factors may seem to be insignificant on one project, they may prove to be significant on some another project, as conditions are not always the same.

Kaming et al [7] classified factors influencing construction time and cost overruns in Indonesia and analyzed the correlation between the two. The scope of their particular research was only focuses on the high-rise projects. Dissanayaka and Kumaraswamy [13] identified and grouped factors significantly related to time and cost performance and then developed the time and cost overrun models. Recently Aziz et al [14] found that cost was one of the 
Table 1. Classification of factors causing cost overrun.

\begin{tabular}{|c|c|c|c|c|}
\hline $\begin{array}{l}\text { No index } \\
\text { entries } \\
\text { found }\end{array}$ & $\begin{array}{l}\text { Factor affecting cost } \\
\text { overrun }\end{array}$ & References & Code & $\begin{array}{l}\text { Finalisied Factors for } \\
\text { Questionnare survey }\end{array}$ \\
\hline $\begin{array}{l}2 \\
3\end{array}$ & $\begin{array}{c}\text { Price escalation of raw } \\
\text { materials } \\
\text { High cost of labour } \\
\text { High cost of transportation }\end{array}$ & $\begin{array}{c}\text { Frimpong et al [5], Moura et al [8], Kaliba et al [6], Rahman } \\
\text { et al [22], Kaming et al [7] } \\
\text { Kaming et al [7], Azhar et al }[9,10] \\
\text { Eshofonie and Patience [23] }\end{array}$ & $\mathrm{C} 01$ & $\begin{array}{c}\text { Price escalation of raw } \\
\text { materials }\end{array}$ \\
\hline 4 & Dispute on bill settlement & Ameh et al [24], Sharma and Goyal [25] & $\mathrm{C} 02$ & $\begin{array}{l}\text { Dispute on bill } \\
\text { settlement }\end{array}$ \\
\hline $\begin{array}{l}5 \\
6\end{array}$ & $\begin{array}{l}\text { Delay in planned activity } \\
\text { Long period between design } \\
\text { and tendering time }\end{array}$ & $\begin{array}{c}\text { Harisweni [12], Kaliba et al [6], Rahman et al [22] } \\
\text { Eshofonie and Patience [23] }\end{array}$ & $\mathrm{C} 03$ & $\begin{array}{l}\text { Delay in planned } \\
\text { activity }\end{array}$ \\
\hline 8 & $\begin{array}{l}\text { Ambiguous or incomplete } \\
\text { tender document } \\
\text { Contract management }\end{array}$ & $\begin{array}{l}\text { Omoregie and Radford n.d. [26], Rosenfeld [27], Sharma } \\
\text { and Goyal [25] } \\
\text { Mansfield et al [28], Eshofonie and Patience [23], Doloi } \\
\text { [29] }\end{array}$ & $\mathrm{C} 04$ & $\begin{array}{l}\text { Ambiguous or } \\
\text { incomplete tender } \\
\text { document }\end{array}$ \\
\hline 9 & Additional Work & Le-Hoai et al [17], Sharma and Goyal [25] & $\mathrm{C} 05$ & Additional Work \\
\hline 10 & Frequent design changes & $\begin{array}{c}\text { Kaming et al. [7], Frimpong et al [5], Omoregie and } \\
\text { Radford [26], Harisweni [12], Le-Hoai et al [17], Azhar } \\
\text { et al [9, 10], Cheng [30] } \\
\text { Kaming et al [7], Frimpong et al [5], Moura et al [8], } \\
\text { Rahman et al [22], Kaliba et al [6] }\end{array}$ & C06 & $\begin{array}{c}\text { Frequent design } \\
\text { changes }\end{array}$ \\
\hline 12 & $\begin{array}{c}\text { Lack of co-ordination } \\
\text { between construction } \\
\text { parties } \\
\text { Poor site management and } \\
\text { supervision }\end{array}$ & Azhar et al $[9,10]$, Sharma and Goyal [25] & $\mathrm{C} 07$ & $\begin{array}{c}\text { Lack of co-ordination } \\
\text { between } \\
\text { construction parties }\end{array}$ \\
\hline 15 & $\begin{array}{l}\text { Fraudulent practices and } \\
\text { kick backs } \\
\text { Supplier manipulation }\end{array}$ & $\begin{array}{c}\text { Omoregie and Radford [26], Azhar et al [9, 10], Doloi [29], } \\
\text { Sharma and Goyal [25] } \\
\text { Eshofonie and Patience [23] }\end{array}$ & $\mathrm{C} 08$ & $\begin{array}{l}\text { Fraudulent practices } \\
\text { and kick backs }\end{array}$ \\
\hline 16 & Mistake during construction & Eshofonie and Patience [23] & C09 & $\begin{array}{l}\text { Mistake during } \\
\text { construction }\end{array}$ \\
\hline 17 & Force Majeure & Kaliba et al [6], Kaming et al [7], Frimpong et al [5] & $\mathrm{C} 10$ & Force Majeure \\
\hline 18 & $\begin{array}{l}\text { High quality expectation } \\
\text { from owner }\end{array}$ & Cheng [30], Shanmugapriya and Subramanian [31] & $\mathrm{C} 11$ & $\begin{array}{l}\text { High quality } \\
\text { expectation from } \\
\text { owner }\end{array}$ \\
\hline 19 & $\begin{array}{l}\text { Contractual claims, such as, } \\
\text { extension of time with } \\
\text { cost claims }\end{array}$ & Rahman et al [22] & $\mathrm{C} 12$ & $\begin{array}{l}\text { Shortening of contract } \\
\text { period }\end{array}$ \\
\hline 20 & $\begin{array}{l}\text { Shortening of contract } \\
\text { period }\end{array}$ & Omoregie and Radford [26], Okpala and Aniekwu[32] & & \\
\hline 21 & Wastage on site & Shanmugapriya and Subramanian [31] & $\mathrm{C} 13$ & Wastage on site \\
\hline 22 & $\begin{array}{l}\text { Relationship between site } \\
\text { management and labour }\end{array}$ & Omoregie and Radford [26], Rahman et al [22], Doloi [29] & $\mathrm{C} 14$ & $\begin{array}{l}\text { Relationship between } \\
\text { site management } \\
\text { and labour }\end{array}$ \\
\hline 23 & $\begin{array}{l}\text { Poor financial control on } \\
\text { site }\end{array}$ & Azhar et al [9, 10], Ameh et al [24], Doloi [29] & $\mathrm{C} 15$ & $\begin{array}{l}\text { Poor financial control } \\
\text { on site }\end{array}$ \\
\hline 24 & $\begin{array}{c}\text { Cash flow and financial } \\
\text { difficulties faced by } \\
\text { contractors }\end{array}$ & $\begin{array}{c}\text { Frimpong et al [5], Le-Hoai et al [17], Rahman et al [22], } \\
\text { Doloi [29] }\end{array}$ & & \\
\hline 25 & $\begin{array}{l}\text { Financial difficulties of } \\
\text { owner }\end{array}$ & Koushki et al [16], Rahman et al [22] & & \\
\hline
\end{tabular}

major consideration throughout out the project management life cycle for waste management project in Egypt. It was discovered the factors such as lowest bidding procurement method, bureaucracy in bidding/tendering method, additional work; wrong method of cost estimation; funding problems were critical for enhancing cost variation. 
Rahman et al [15] found that the top three significant factors of cost overrun are fluctuation of prices of materials, financial difficulties faced by contractors and poor site management and supervision in Malaysia. Frimpong et al [5] identified causes of delay and cost overrun in construction of projects in Ghana. They identified 26 factors related to cost overruns and delays. Out of which, monthly payment difficulties from agencies, poor contract management, poor technical performances, material procurement, and escalation of material prices were the top five factors causing time and cost overruns.

With survey of 450 randomly selected private residential project owners and developers in Kuwait, Koushki et al provided model to estimates of cost increases and time delays and their causes [16]. The three main traits of cost overruns were contractor related problem, material related problem and owner's financial constraints. In order to minimize time and cost overruns, they recommended that project owner should allocate sufficient time and money at design phase, availability of sufficient funds, and selection of proficient consultant and trustworthy contractor to carry out the work. A questionnaire survey was conducted in Portugal by Moura et al [8] found that design error, direct change in order and different site conditions were the top three factors affecting cost overruns. In Pakistan, Azhar et al $[9,10]$ carried out a questionnaire survey consisting of 42 factors affecting cost overruns with 25 sets of responses. It was concluded that medium size firms were more prone to cost overruns in comparison with large and small firms because they were in transitional phase where they need to take more risk to find more business and establish them. It was found that fluctuation in prices of raw material, high cost of machineries, unstable cost of manufactured materials, lowest bidding procurement method, and poor site management were the top five factors governing cost overruns.

Le-Hoai et al [17] studied factors affecting cost overruns and time overruns in Vietnam and found top three factors which governed time and cost overruns were poor site management and supervision, poor project management assistance, and financial difficulties of owner. Kaliba et al [6] researched in Zambia and found that delayed payments, financial processes and difficulties on the part of contractors and clients, and contract modification were top three causes. In United Kingdom, Olawale and Sun [18] identified top three causes affecting cost overruns as design changes, risk and uncertainty associated with project and inaccurate evaluation of project's time or duration. Across the world, many researchers have conducted studies on project cost overruns problem found different factors. However, no counties have similar factors responsible for cost overrun which could be due to political, regional variations of nations. India very few studies have been conducted, which have limitation of regional location. So it is necessary to study this cost overrun aspect throughout India, with all types of organizations such as client oriented, consultant oriented and contractor oriented.

\section{Methodology}

A questionnaire study was designed with 15 prominent questions related to cost overrun in table 2. It was sent to 190 construction professionals across India (northern region, southern region, western region, eastern region and central regions).

\subsection{Questionnaire design}

Sets of 25 important factors were shortlisted form the references of various literatures around the world related to cost overrun. As a part of preliminary study, advice was taken from experts for shortlisting important factors causing cost overrun in construction industry. Questionnaire studies were conducted to find various factors affecting cost overrun in Indian scenario. Then this could have helped some technocrat and bureaucrat to take corrective action for future project investment in India.

\subsection{Data collection}

The questionnaire were distributed to 190 personal across India by mail during October 2014 to April 2015 among professionals working in the construction industry, and subsequently followed up to obtain responses. To get the opinion of the factors affecting cost overruns, four options (1. agree, 2. partially agree, 3. partially disagree and 4 . disagree) were given where respondents were asked to mark their level of agreement to each question. The

Table 2. Factors causing cost overrun.

\begin{tabular}{lc}
\hline Code & Finalised factors for questionnaire survey \\
\hline C01 & Price escalation of raw material \\
C02 & Dispute on bill settlement \\
C03 & Delay in planned activity \\
C04 & Additional work \\
C05 & Frequent design changes \\
C06 & Lack of co-ordination between construction parties \\
C07 & Fraudulent practices and kick backs \\
C08 & Mistake during construction \\
C09 & Force majeure \\
C10 & High quality expectation from owner \\
C11 & Shortening of contract period \\
C12 & Wastage on site \\
C13 & Poor financial control on site \\
C14 & Relationship between site management and labour \\
C15 & \\
\hline
\end{tabular}


respondents were given an additional option of "no idea" in case if a respondent never came across of such factor.

In this research, a four point Likert scale was adopted in view of its ease and fittingness for assessing the outcome of each factor on the project cost overruns, derived from the respondents' own decision based on working experience throughout their professional career in construction industry. In order to examine the study of the responses, numerical values were allocated to the respondents' opinion as follows:

- Agree - 4

- Partially agree - 3

- Partially disagree - 2

- Disagree - 1

- No idea - Response not considered during analysis

\subsection{Respondent's profile}

Based on the data collected from the respondents, the factors were investigated for their relative importance among each respondents' category. The questionnaires were distributed randomly among 190 construction personnel working across India in which 64 were clients, 32 were consultants and 94 were contractors. Eighty-five sets of questionnaire were received successfully, from which clients, consultants and contractors were 33, 10 and 44 respectively. The response rate was observed as $52 \%$ for client, $31 \%$ for consultants and $44 \%$ for contractor, which showed overall response rate of nearly $45 \%$, and it may be acceptable for such study which was shown in table 3 .

The data was collected from all over India with the division into five parts namely East, West, Central, North and South. Responses came from different regions of India were shown in table 4. Main purpose of the collection of data from various regions was to ensure that the data should represent overall scenario of Indian construction industry.

The data was also collected for the cost of current project in order to have common idea about the respondents which observed that 23 respondents were involved in projects worth less than Rs. 10 Cr. (<US \$ 2 million), 28 respondents were involved in projects worth between Rs. 10 and 50 Cr. (US \$ 2-10 million), 19 respondents were involved in projects worth between Rs. 50 and $100 \mathrm{Cr}$ (US \$ 10-20 million) and 15 respondents were involved in projects worth more than $100 \mathrm{Cr}$. (US \$ 20 million) as showed in figure 1.

\section{Results and discussions}

The statistical analysis was done on the respondents' data using IBM SPSS 22 package. In order to check suitability of the data for further analysis, reliability analysis is to be done initially.

Table 3. Respondents profile based on type of organization.

\begin{tabular}{lcccr}
\hline Description & Number of copied distributed & Number of respondents & Response rate \% & Percentage of number of responses \\
\hline Client & 64 & 33 & 52 & 39 \\
Consultant & 32 & 10 & 31 & 12 \\
Contractor & 94 & 42 & 44 & 49 \\
Total & 190 & 85 & 45 & 100 \\
\hline
\end{tabular}

Table 4. Respondents profile based on working zone in India.

\begin{tabular}{|c|c|c|}
\hline Working zone in India & Frequency & Percent \\
\hline North & 7 & 8.2 \\
\hline South & 13 & 15.3 \\
\hline East & 5 & 5.9 \\
\hline West & 47 & 55.3 \\
\hline Central & 13 & 15.3 \\
\hline Total & 85 & 100 \\
\hline
\end{tabular}




\subsection{Reliability analysis}

Reliability analysis is a technique to verify the internal consistency of the data having multiple scales. Reliability test could be carried out by obtaining various reliability coefficients in which the most commonly used is Cronbach alpha. Reliability of the data is considered as at low level when Cronbach alpha is less than 0.3 which means the data is not suitable for further analysis whereas reliability of the data is considered as high level when Cronbach alpha is more than 0.7 which implies that data is suitable for further analysis.

To check the reliability of data, Cronbach alpha was computed for factors using the formula given in Eq. (1). In

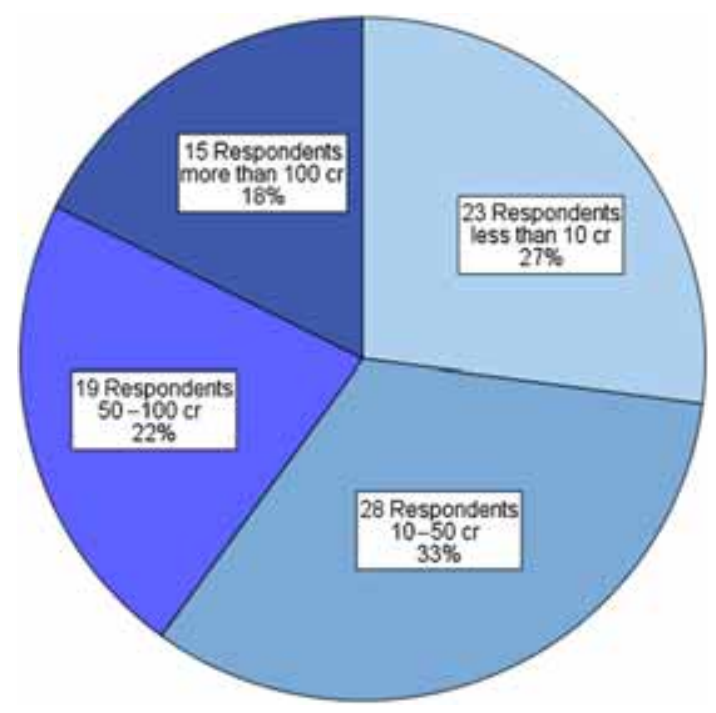

Figure 1. Respondent profile based on cost of current project. this study, Cronbach's alpha was computed using software SPSS 22.

$$
\alpha=\frac{N \cdot \bar{c}}{\bar{v}+(N-1) \bar{c}},
$$

where $\alpha$ is Cronbach alpha, $N$ is number of items, $\bar{c}$ is average inter-item covariance among the items, and $\bar{v}$ is average variance.

The computed value of Cronbach's alpha for cost overrun factors was 0.721 which is greater than 0.7 . Therefore, data obtained from respondents was reliable and could be used for further analysis.

\subsection{Ranking of factors}

The rankings of factors were carried from the opinion of respondent who were fully agree with that particular factors. All other marks such as partially agreed, partially disagreed and not agreed. Frequency count was done based on types of organization, location/various zones in India, type and size of projects, experiences of the respondents.

4.2a Types of organization: The factors causing cost variation for construction project is tabulated in table 5 using SPSS. Number of respondents who were agreed to cause of cost variation are ranked together. The feedback from client, consultant and contractors, who were marked as "Agree", counted in the "Total" and it is sorted out from largest to smallest value in Excel sheet. Percentage of persons from the samples who agreed on particular factor causing cost variation was calculated out of total count of 85 numbers. From table 5, 67\% respondents had fully agreed on price escalation of raw materials caused cost overrun of project in India. Second and third they were

Table 5. Ranking of factors on type of organization.

\begin{tabular}{|c|c|c|c|c|c|c|c|}
\hline & Factors causing cost overrun & $\begin{array}{c}\text { Client } \\
\text { Agree } \\
\text { (33) Count }\end{array}$ & $\begin{array}{l}\text { Consultant } \\
\text { Agree } \\
\text { (10) Count }\end{array}$ & $\begin{array}{c}\text { Contractors } \\
\text { Agree } \\
\text { (42) Count }\end{array}$ & $\begin{array}{c}\text { Total } \\
\text { Agree } \\
\text { (85) Count }\end{array}$ & $\begin{array}{c}\text { Percentage } \\
\text { Agree } \\
\%\end{array}$ & $\begin{array}{l}\text { Rank } \\
\text { Agree } \\
\text { Coun }\end{array}$ \\
\hline $\mathrm{C} 1$ & Price escalation of raw material & 22 & 4 & 31 & 57 & 67 & $\mathrm{R} 1$ \\
\hline $\mathrm{C} 3$ & Delay in planned activity & 13 & 6 & 22 & 41 & 48 & $\mathrm{R} 2$ \\
\hline $\mathrm{C} 7$ & Lack of co-ordination between construction parties & 7 & 8 & 24 & 39 & 46 & $\mathrm{R} 3$ \\
\hline $\mathrm{C} 5$ & Additional work/extra items & 8 & 5 & 25 & 38 & 45 & $\mathrm{R} 4$ \\
\hline C6 & Frequent changes in design & 8 & 4 & 26 & 38 & 45 & R5 \\
\hline $\mathrm{C} 13$ & Wastage on site & 15 & 4 & 14 & 33 & 39 & R6 \\
\hline $\mathrm{C} 15$ & Poor financial control on site & 11 & 6 & 15 & 32 & 38 & R7 \\
\hline $\mathrm{C} 2$ & Dispute on bill settlement & 8 & 1 & 22 & 31 & 36 & $\mathrm{R} 8$ \\
\hline $\mathrm{C} 4$ & Ambiguous or incomplete tender document & 5 & 5 & 21 & 31 & 36 & $\mathrm{R} 9$ \\
\hline $\mathrm{C} 12$ & Shorting of contract period & 4 & 1 & 25 & 30 & 35 & $\mathrm{R} 10$ \\
\hline $\mathrm{C} 11$ & High quality expectation from owner & 3 & 2 & 24 & 29 & 34 & $\mathrm{R} 11$ \\
\hline $\mathrm{C} 8$ & Fraudulent practices and kick backs & 15 & 5 & 8 & 28 & 33 & R12 \\
\hline $\mathrm{C} 9$ & Mistake during construction & 14 & 3 & 6 & 23 & 27 & $\mathrm{R} 13$ \\
\hline $\mathrm{C} 14$ & Relationship between site management and labour & 8 & 3 & 11 & 22 & 26 & $\mathrm{R} 14$ \\
\hline $\mathrm{C} 10$ & Force majeure & 2 & 3 & 3 & 8 & 9 & R15 \\
\hline
\end{tabular}


agreed on "delay in planned activity" and "lack of coordination between construction parties" could be the major three reason of cost overrun. It has also observed that majority of responded from client organization such as public works department, govenment department were agree on "price escalation of raw materials" caused largely on cost overun out of 15 identified factor given to them. However consultant did not much agree upon the view of client or contractors, they are more inclined toward "Lack of co-ordination between Construction Parties" and voted eight respondents on fully agree out of 10 respondents. Similar factors were identified by Frimpong as escalation of materials prices and poor site management were two factors out of five significant factors causing cost overrun in Ghana. Poor project management and supervision in Vietnam [17]. However delayed payments, financial processes [6], design changes, risk, inaccurate evaluation of projects time and duration [18] were also identified as prominent factors causing of cost overrun of construction project. Hence the factors causing of cost overrun have varied from country to country.

4.2b Location/various zones in India: Views of respondent from various zones such as North, South, East, West and Central India have reported in table 6. Respondent from North, West and Central zone of India had fully agreed on price escalation of raw material causes cost overrun however south zone responded agreed upon delay in planned activity and poor financial control on site. And East zone respondent agreed on frequent changes in design at construction site. Hence larger parts of India such as North, West and Central zone have agreed with price escalation of raw materials.

4.2c Value of projects: Most of the responses were received from Rs. 10-50 crore projects and 10 crore projects as shown in table 7 . Twenty-two out of 28 respondents agreed on price escalation of raw materials causes cost overrun in $10-50$ crore project. Furthermore 17 out of 23 respondents agreed on price escalation of raw material causes cost overrun in less than 10 crores projects. However, 12 respondents out of 15 from more than 100 crore project agreed for delay in planned activities caused the cost overrun of construction project. Azhar also found medium size firms were more prone to cost overrun due to fluctuation in prices of raw materials as compare to large firms $[9,10]$. Hence for small project up to 50 crores, respondent believed price escalation of raw materials causes cost overrun whereas big projects costing more than $100 \mathrm{cr}$, respondent believed on delayed in planned activities causes cost over.

4.2d Experiences of respondents: To review the opinion of respondent, majority of the respondents in the survey were from 5 to 10 years of experiences group and their opinions are valuable as more than 5 years of construction project experience are quite better. As the experience of respondent is higher and higher, weighable of opinion are more and more valuable. In this study 31 respondents out of 42 in the years of 5-10 years of experience have agreed on price escalation of raw materials could cause the cost overrun of the project.

Table 6. Ranking of factors based on working zone in India.

\begin{tabular}{|c|c|c|c|c|c|c|c|c|c|}
\hline & & $\begin{array}{l}\text { North } \\
\text { Agree } \\
\text { (7) }\end{array}$ & $\begin{array}{c}\text { South } \\
\text { Agree } \\
(13)\end{array}$ & $\begin{array}{c}\text { East } \\
\text { Agree } \\
(5)\end{array}$ & $\begin{array}{c}\text { West } \\
\text { Agree } \\
(47)\end{array}$ & $\begin{array}{c}\text { Central } \\
\text { Agree } \\
(13)\end{array}$ & $\begin{array}{c}\text { Total } \\
\text { Agree } \\
(85)\end{array}$ & $\begin{array}{c}\text { Percentage } \\
\text { Agree }\end{array}$ & $\begin{array}{l}\text { Rank } \\
\text { Agree }\end{array}$ \\
\hline & Factors causing cost overrun & Count & Count & Count & Count & Count & Count & $\%$ & \\
\hline $\mathrm{C} 1$ & Price escalation of raw material & 6 & 6 & 2 & 33 & 10 & 57 & 67 & $\mathrm{R} 1$ \\
\hline C3 & Delay in planned activity & 1 & 8 & 2 & 22 & 8 & 41 & 48 & $\mathrm{R} 2$ \\
\hline $\mathrm{C} 7$ & $\begin{array}{c}\text { Lack of co-ordination between } \\
\text { construction parties }\end{array}$ & 3 & 7 & 2 & 22 & 5 & 39 & 46 & R3 \\
\hline $\mathrm{C} 5$ & Additional work/extra items & 3 & 6 & 2 & 20 & 7 & 38 & 45 & $\mathrm{R} 4$ \\
\hline C6 & Frequent changes in design & 4 & 5 & 3 & 20 & 6 & 38 & 45 & R5 \\
\hline C13 & Wastage on site & 3 & 4 & 2 & 19 & 5 & 33 & 39 & R6 \\
\hline $\mathrm{C} 15$ & Poor financial control on site & 0 & 8 & 3 & 19 & 2 & 32 & 38 & R7 \\
\hline $\mathrm{C} 4$ & $\begin{array}{c}\text { Ambiguous or incomplete tender } \\
\text { document }\end{array}$ & 3 & 7 & 0 & 17 & 4 & 31 & 36 & $\mathrm{R} 8$ \\
\hline $\mathrm{C} 2$ & Dispute on bill settlement & 4 & 4 & 2 & 14 & 7 & 31 & 36 & R9 \\
\hline $\mathrm{C} 12$ & Shorting of contract period & 2 & 5 & 2 & 18 & 3 & 30 & 35 & $\mathrm{R} 10$ \\
\hline C11 & High quality expectation from owner & 3 & 6 & 0 & 16 & 4 & 29 & 34 & R11 \\
\hline $\mathrm{C} 8$ & Fraudulent practices and kick backs & 1 & 3 & 2 & 18 & 4 & 28 & 33 & $\mathrm{R} 12$ \\
\hline C9 & Mistake during construction & 0 & 4 & 0 & 17 & 2 & 23 & 27 & $\mathrm{R} 13$ \\
\hline C14 & $\begin{array}{l}\text { Relationship between site management } \\
\text { and labour }\end{array}$ & 0 & 7 & 0 & 15 & 0 & 22 & 26 & R14 \\
\hline $\mathrm{C} 10$ & Force majeure & 1 & 1 & 0 & 6 & 0 & 8 & 9 & $\mathrm{R} 15$ \\
\hline
\end{tabular}


Table 7. Ranking of factors based on value of projects.

\begin{tabular}{|c|c|c|c|c|c|c|c|c|}
\hline & Factors causing cost overrun & $\begin{array}{c}\text { Less than } 10 \\
\text { cr } \\
\text { Agree } \\
\text { (23) Count }\end{array}$ & $\begin{array}{c}10-50 \mathrm{cr} \\
\text { Agree } \\
(28) \\
\text { Count }\end{array}$ & $\begin{array}{c}50-100 \\
\text { cr } \\
\text { Agree } \\
(19) \\
\text { Count }\end{array}$ & $\begin{array}{l}\text { More than } \\
100 \mathrm{cr} \\
\text { Agree } \\
\text { (15) Count }\end{array}$ & $\begin{array}{c}\text { Total } \\
\text { Agree } \\
(85) \\
\text { Count }\end{array}$ & $\begin{array}{c}\text { Percentage } \\
\text { Agree } \\
\%\end{array}$ & $\begin{array}{l}\text { Rank } \\
\text { Agree } \\
\text { Count }\end{array}$ \\
\hline $\mathrm{C} 1$ & Price escalation of raw material & 17 & 22 & 10 & 8 & 57 & 67 & $\mathrm{R} 1$ \\
\hline $\mathrm{C} 3$ & Delay in planned activity & 12 & 11 & 6 & 12 & 41 & 48 & $\mathrm{R} 2$ \\
\hline $\mathrm{C} 5$ & Additional work/extra items & 15 & 11 & 7 & 7 & 40 & 46 & R3 \\
\hline C6 & Frequent changes in design & 12 & 11 & 10 & 6 & 39 & 45 & $\mathrm{R} 4$ \\
\hline $\mathrm{C} 7$ & $\begin{array}{c}\text { Lack of co-ordination between } \\
\text { construction parties }\end{array}$ & 14 & 12 & 6 & 7 & 39 & 45 & R5 \\
\hline $\mathrm{C} 13$ & Wastage on site & 8 & 14 & 6 & 5 & 33 & 39 & R6 \\
\hline $\mathrm{C} 15$ & Poor financial control on site & 12 & 8 & 4 & 8 & 32 & 38 & $\mathrm{R} 7$ \\
\hline $\mathrm{C} 2$ & Dispute on bill settlement & 8 & 10 & 10 & 3 & 31 & 36 & $\mathrm{R} 8$ \\
\hline $\mathrm{C} 4$ & $\begin{array}{c}\text { Ambiguous or incomplete tender } \\
\text { document }\end{array}$ & 9 & 10 & 5 & 7 & 31 & 36 & R9 \\
\hline $\mathrm{C} 12$ & Shorting of contract period & 9 & 11 & 5 & 5 & 30 & 35 & $\mathrm{R} 10$ \\
\hline $\mathrm{C} 11$ & High quality expectation from owner & 10 & 11 & 6 & 2 & 29 & 34 & $\mathrm{R} 11$ \\
\hline $\mathrm{C} 8$ & Fraudulent practices and kick backs & 7 & 14 & 4 & 3 & 28 & 33 & $\mathrm{R} 12$ \\
\hline C9 & Mistake during construction & 7 & 11 & 3 & 2 & 23 & 27 & $\mathrm{R} 13$ \\
\hline C14 & $\begin{array}{l}\text { Relationship between site management } \\
\text { and labour }\end{array}$ & 6 & 8 & 6 & 2 & 22 & 26 & R14 \\
\hline $\mathrm{C} 10$ & Force majeure & 3 & 2 & 0 & 3 & 8 & 9 & $\mathrm{R} 15$ \\
\hline
\end{tabular}

Similarly in the age group of 10-15 years, 9 out of 13 respondents were agreed on as shown in table 8 .

Price escalation of raw material was ranked first by both client and contractor. Possible explanation could be that price escalation in material has to be borne by the client and also affects the contractor as they have to initially pay for it till payment of the running bills, however the consultant plays an advisory role and not involved in the fluctuation in the material price.

\subsection{Anova}

The one way ANOVA test was used for comparison of means of more than two groups of an independent variable. The aim was to test for the differences in means of the dependent variable broken down by the levels of independent variable. In this analysis, the independent variable was taken as 'working zone in India' which was tested against all the dependent variables i.e. the factors responsible for cost overruns. The exercise was undertaken in order to verify the similarity in opinions among the construction professionals from various regions of the nation.

The null and alternative hypothesis was formed to examine in the difference of opinions among the construction professionals from different regions in India which are as follows:

Null hypothesis $\left(\mathrm{H}_{\mathrm{o}}\right)$ - There is no significance difference in the opinion for factors affecting cost overruns among construction professionals from different regions of India.
Alternate hypothesis $\left(\mathrm{H}_{\mathrm{a}}\right)$ - There is significant difference in the opinion for factors affecting cost overruns among construction professionals from different regions of India.

With the significance level of 0.05 , the data was tested to check agreement among the construction professionals from different working zones for their opinions about factors responsible for cost overruns and result obtained from software SPSS were as shown in table 9. It was observed from table 9 that the construction professionals across India were agreed upon 14 out of 15 factors responsible for cost overruns at a significance level 0.05 . Opinion of construction professionals was significantly different for only one factor 'Mistake during construction'. Thus null hypothesis was not able to reject hence the null hypothesis was accepted for 14 factors. Therefore, there is no significant difference among construction professionals in opinion for cost overrun factors from different regions of India.

\subsection{Factor analysis}

Factor analysis is a method of data reduction which is used for reducing large number of factors to a small number of component factors. It is a useful method for investigating factors relationship for compound concepts.

4.4a Co-relation matrix of variable: The purpose of forming co-relation matrix was to obtain the determinant of the matrix which was useful to identify multi-co-linearity and singularity of data [19]. Value of the determinant obtained from co-relation matrix should be greater than 0.00001 . 
Table 8. Ranking of factors based on experiences of respondents.

\begin{tabular}{|c|c|c|c|c|c|c|c|c|c|}
\hline & & $\begin{array}{c}0-5 \\
\text { years } \\
\text { Agree } \\
(13)\end{array}$ & $\begin{array}{l}5-10 \\
\text { years } \\
\text { Agree } \\
(42)\end{array}$ & $\begin{array}{l}10-15 \\
\text { years } \\
\text { Agree } \\
(13)\end{array}$ & $\begin{array}{l}15-20 \\
\text { years } \\
\text { Agree } \\
(10)\end{array}$ & $\begin{array}{c}\text { more than } 20 \\
\text { years } \\
\text { Agree }\end{array}$ & $\begin{array}{c}\text { Total } \\
\text { Agree } \\
(85)\end{array}$ & $\begin{array}{l}\text { Percentage } \\
\text { Agree }\end{array}$ & $\begin{array}{l}\text { Rank } \\
\text { Agree }\end{array}$ \\
\hline Code & Factors causing cost overrun & Count & & & & (7) Count & & $\%$ & Count \\
\hline $\mathrm{C} 01$ & Price escalation of raw material & 8 & 31 & 9 & 5 & 4 & 57 & 67 & $\mathrm{R} 1$ \\
\hline $\mathrm{C} 03$ & Delay in planned activity & 7 & 23 & 4 & 3 & 4 & 41 & 48 & $\mathrm{R} 2$ \\
\hline $\mathrm{C} 05$ & Additional work/Extra items & 6 & 23 & 4 & 4 & 3 & 40 & 46 & $\mathrm{R} 3$ \\
\hline $\mathrm{C} 07$ & $\begin{array}{c}\text { Lack of co-ordination between } \\
\text { construction parties }\end{array}$ & 4 & 22 & 6 & 3 & 5 & 40 & 45 & $\mathrm{R} 4$ \\
\hline $\mathrm{C} 06$ & Frequent changes in design & 4 & 21 & 7 & 3 & 3 & 38 & 45 & R5 \\
\hline $\mathrm{C} 13$ & Wastage on site & 6 & 15 & 6 & 4 & 2 & 33 & 39 & R6 \\
\hline $\mathrm{C} 15$ & Poor financial control on site & 5 & 16 & 4 & 3 & 4 & 32 & 38 & R7 \\
\hline $\mathrm{C} 02$ & Dispute on bill settlement & 4 & 13 & 8 & 5 & 1 & 31 & 36 & $\mathrm{R} 8$ \\
\hline $\mathrm{C} 04$ & $\begin{array}{l}\text { Ambiguous or incomplete tender } \\
\text { document }\end{array}$ & 7 & 16 & 4 & 1 & 3 & 31 & 36 & R9 \\
\hline $\mathrm{C} 12$ & Shorting of contract period & 5 & 15 & 6 & 3 & 1 & 30 & 35 & $\mathrm{R} 10$ \\
\hline $\mathrm{C} 11$ & High quality expectation from owner & 4 & 14 & 6 & 2 & 3 & 29 & 34 & $\mathrm{R} 11$ \\
\hline $\mathrm{C} 08$ & Fraudulent practices and kick backs & 5 & 11 & 6 & 2 & 4 & 28 & 33 & $\mathrm{R} 12$ \\
\hline C09 & Mistake during construction & 4 & 12 & 4 & 0 & 3 & 23 & 27 & $\mathrm{R} 13$ \\
\hline $\mathrm{C} 14$ & $\begin{array}{l}\text { Relationship between site } \\
\text { management and labour }\end{array}$ & 6 & 10 & 3 & 1 & 2 & 22 & 26 & $\mathrm{R} 14$ \\
\hline $\mathrm{C} 10$ & Force majeure & 5 & 3 & 1 & 0 & 0 & 8 & 9 & $\mathrm{R} 15$ \\
\hline
\end{tabular}

Table 9. ANOVA - 'working zone in India' and ' factor affecting cost overrun'.

\begin{tabular}{|c|c|c|c|c|c|}
\hline Factors affecting cost overruns & Sum of squares & df & Mean square & $\mathrm{F}$ & Sig. \\
\hline Lack of co-ordination between construction parties & 0.546 & 4 & 0.136 & 0.201 & 0.937 \\
\hline Additional work/extra items & 0.738 & 4 & 0.184 & 0.217 & 0.928 \\
\hline Wastage on site & 1.049 & 4 & 0.262 & 0.253 & 0.907 \\
\hline Frequent changes in design & 1.042 & 4 & 0.261 & 0.292 & 0.882 \\
\hline Dispute on bill settlement & 1.212 & 4 & 0.303 & 0.331 & 0.857 \\
\hline Shorting of contract period & 3.059 & 4 & 0.765 & 0.659 & 0.622 \\
\hline Fraudulent practices and kick backs & 3.775 & 4 & 0.944 & 0.837 & 0.506 \\
\hline Relationship between site management and labour & 2.795 & 4 & 0.699 & 1.032 & 0.396 \\
\hline Ambiguous or incomplete tender document & 5.419 & 4 & 1.355 & 1.036 & 0.394 \\
\hline Force majeure & 4.557 & 4 & 1.139 & 1.084 & 0.370 \\
\hline High quality expectation from owner & 5.012 & 4 & 1.253 & 1.204 & 0.316 \\
\hline Price escalation of raw material & 3.153 & 4 & 0.788 & 1.438 & 0.229 \\
\hline Delay in planned activity & 3.670 & 4 & 0.918 & 1.747 & 0.148 \\
\hline Poor financial control on site & 4.673 & 4 & 1.168 & 1.991 & 0.104 \\
\hline Mistake during construction & 7.901 & 4 & 1.975 & 3.219 & 0.017 \\
\hline
\end{tabular}

Co-relation matrix was also useful to find out KaiserMeyer-Olkin (KMO) which is the measure of sampling adequacy. The obtained value of KMO should be greater than 0.5 for data being adequate [20].

The co-relation matrix for variables of cost overruns was obtained from software IBM SPSS package 22 which was shown in table 10. The determinant of correlation matrix was 0.003 which was considered as being adequate $(>0.000$ 01), which indicated that neither matrix have multicollinearity or singularity [19]. The Kaiser-Meyer-Olkin (KMO) measure of sampling adequacy was found to be
0.674 which was greater than 0.50. Additionally, significance level of Bartlett test was observed as 0.001 which was less than 0.05 implied that matrix passed through test of identity matrix. These measures confirmed the suitability of the data for proceeding with factor analysis.

4.4b Extraction of factors: Extraction of factors was carried out using software SPSS which was done using principle component analysis (PCA). The basic concept underlying the PCA is that the extracted components explain most of the variance of the correlated variables. 


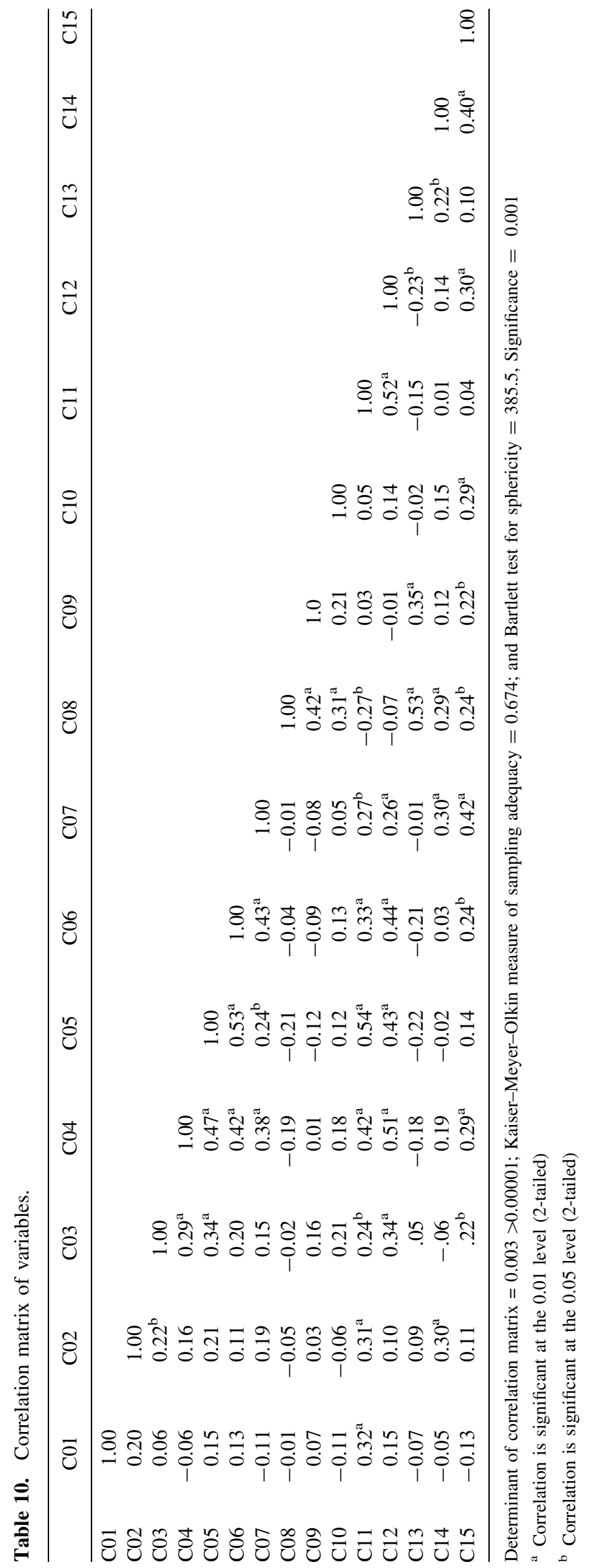


Table 11. Total variance explained.

\begin{tabular}{lccccccc}
\hline & \multicolumn{3}{c}{ Initial Eigen values } & & \multicolumn{3}{c}{ Rotation sums of squared loadings } \\
\cline { 2 - 4 } Component & Total & \% of variance & Cumulative \% n & & Total & \% of variance & Cumulative \% \\
\hline 1 & 5.910 & 39.400 & 39.400 & & 5.452 & 36.346 & 35.346 \\
2 & 2.521 & 16.807 & 56.207 & & 2.849 & 18.993 & 54.338 \\
3 & 1.167 & 7.780 & 63.987 & & 1.371 & 9.140 & 63.478 \\
\hline
\end{tabular}

Table 12. Factor analysis loading results - unrotated.

\begin{tabular}{lcc}
\hline & & Component \\
\cline { 2 - 3 } Variable of cost overruns & CFC1 & CFC2 \\
\hline Additional work/extra items & 0.839 & 0.777 \\
Frequent changes in design & 0.757 & 0.737 \\
Ambiguous or incomplete tender document & 0.730 & 0.556 \\
Shorting of contract period & 0.491 & 0.789 \\
High quality expectation from owner & & 0.672 \\
Lack of co-ordination between construction parties & & 0.591 \\
Delay in planned activity & & 0.549 \\
Fraudulent practices and kick backs & & 0.535 \\
Mistake during construction & & 0.471 \\
Wastage on site & & \\
Relationship between site management and labour & & 0.640 \\
Poor financial control on site & & 0.763 \\
Force majeure & & \\
Price escalation of raw material & & \\
Dispute on bill settlement & & \\
\hline
\end{tabular}

Table 11 was prepared in order to show total variance explained by extracted factors which was obtained as $61 \%$. From table 12, all possible number of extracted factors with Eigen values, percentage of variance and cumulative percentage of variance of factors with initial solution and rotated solution. The initial statistics of total variance explain for cost overruns extracts three factors whose Eigen values were more than 1, explained $63.98 \%$ of total variance. A component with an Eigen value of less than 1 was considered less important therefore it could be ignored [21].

Factor loadings were obtained in table 12 which basically the correlation coefficient linking an original variable and an extracted component factor. The higher the absolute value of the factor loading, the more the variable contributes to that component factor.

4.4c Rotation of matrix: In order to get factor loadings which would understood easily, a VARIMAX rotation was carried out on the factors to reduce the number of factors on which the determinants have high loading [17]. The factors resulting from grouping of the variables using rotation were showed in table 13 in which CFC stands for 'component factor for cost overruns'.

Name of each component was proposed as per their inherent characteristics of the variables present in each component. It was observed from table 14 that the components were named as client control component, project management component, and contractor control component. This would essential, mainly if additional analysis would be conducted on these extracted components.

The factors such as shortening of contract period, high quality expectation from owner, additional work/extra items, poor financial control on site, price escalation of raw material and frequent changes in design was loaded on a single component factor "client control component" as these factors are related to the client. The factors dispute on bill settlement, delay in planned activity, lack of co-ordination between construction parties, ambiguous or incomplete tender document, and relationship between site management and labour get loaded together as a single component CFC 2 as project management component as all the five factors were related to project/site management. Further the factors fraudulent practices and kickbacks, mistake during construction and wastage on site loaded together on a single component contractor control component. Factor loading of the factor force majeure was 0.459 which was less than 0.5 hence it was ignored. The principle components of cost overruns are listed in table 10 using factor analysis with varimax rotation. 
Table 13. Factor analysis loading results using VARIMAX rotation.

\begin{tabular}{llr}
\hline & & Component factor \\
\cline { 2 - 3 } Variable of cost overruns & CFC1 & CFC2 \\
\hline Shorting of contract period & 0.799 & 0.746 \\
High quality expectation from owner & 0.705 & 0.591 \\
Additional work/extra items & 0.568 & 0.819 \\
Poor financial control on site & 0.564 & 0.767 \\
Price escalation of raw material & & 0.723 \\
Frequent changes in design & & 0.545 \\
Dispute on bill settlement & & 0.520 \\
Delay in planned activity & & \\
Lack of co-ordination between construction parties & & \\
Ambiguous or incomplete tender document & & 0.846 \\
Relationship between site management and labour & & 0.757 \\
Fraudulent practices and kick backs & & 0.646 \\
Mistake during construction & & 0.459 \\
Wastage on site & & \\
Force majeure & & \\
\hline
\end{tabular}

Table 14. Factor categories using factor analysis.

\begin{tabular}{lcc}
\hline Component factor & Does cost overrun responsible due to... & Component name \\
\hline CFC 1 & Shorting of contract period & Client control component \\
& High quality expectation from owner & Additional work/extra items \\
& Poor financial control on site \\
& Price escalation of raw material & Frequent changes in design \\
& Dispute on bill settlement & Project management component \\
CFC 2 & Delay in planned activity & Contractor control component \\
& Lack of co-ordination between construction parties \\
Ambiguous or incomplete tender document & Relationship between site management and labour \\
CFC 3 & Fraudulent practices and kick backs \\
& Mistake during construction \\
& Wastage on site \\
\hline
\end{tabular}

\section{Suggestive framework for top three factors}

In this section, tentative solutions are proposed for top three factors affecting cost overruns with framework/model in order to improve efficiency and effectiveness of a project. Top three factors affecting in Indian construction industry were observed as price escalation of raw material, delay in planned activity and lack of co-ordination between construction parties as shown in table 4 . In order to minimize impact of these factors on cost overruns, framework may be proposed as solution.

\subsection{Price escalation of raw materials}

Price escalation of raw material could cause cost overrun of projects was found as rank number 1, by client and contractor in questionnaire survey. Price escalation may be termed as an increase in the cost of construction work performing in a later period of time at a cost higher than originally anticipated in the bid. The suggestive framework is proposed as shown in figure 2 based on after discussion with some of the construction experts/ professional by the authors. In this frame work, if price escalation clause is given in tender document, then it should be borne by client in case material cost has increased. Contractors tendency is least bothers above project progress because escalated cost would be paid by Client. This results into project cost overrun and some time project has slow down due to money shortage. On the other hand, price escalation is not to be included in tender document to then contractor would have to anticipate inflation cost and may quote higher bid with due consideration. There could be three possibilities if inflation is included in the tender document as shown in figure 2 . 


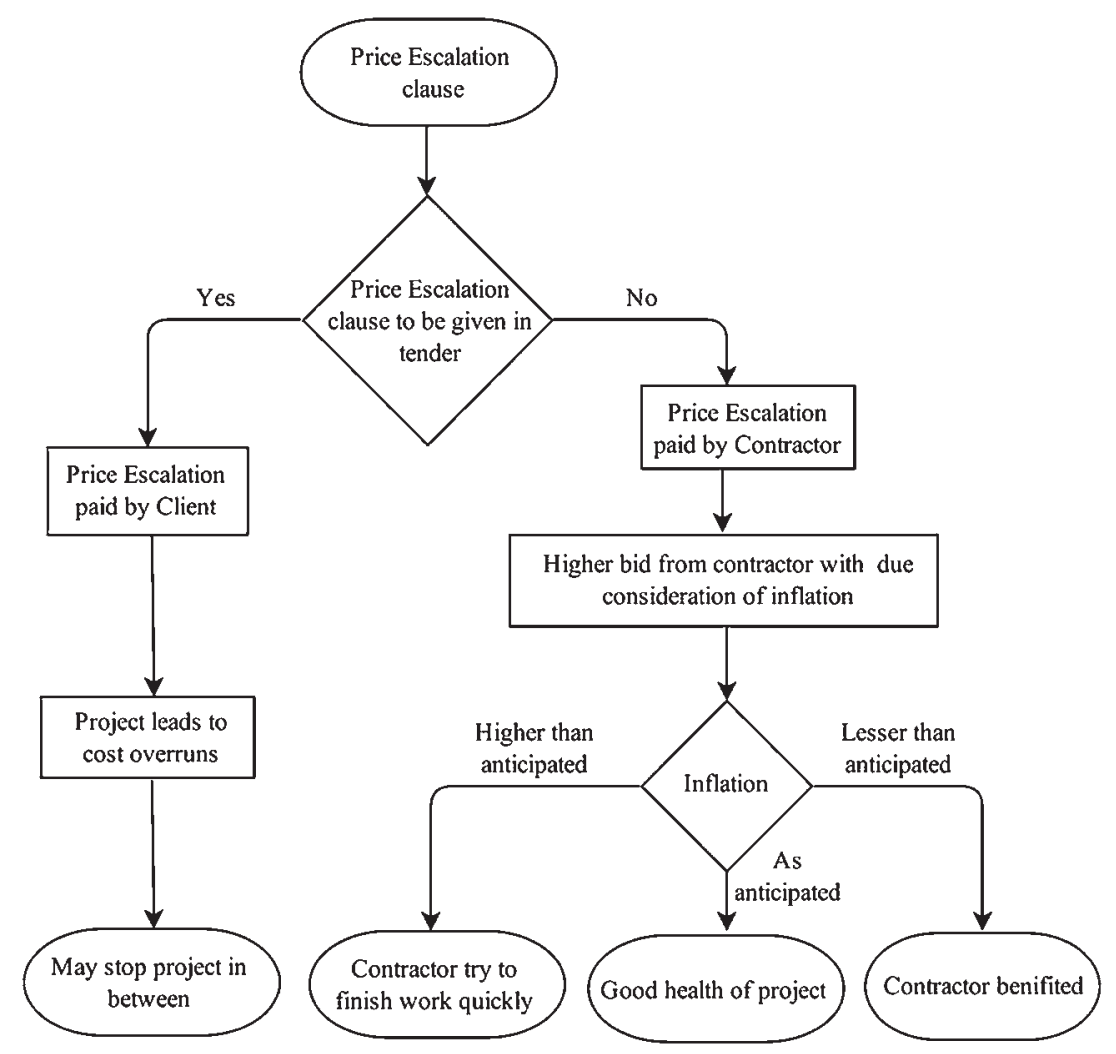

Figure 2. Proposed solution to reduce price escalation of raw material.

i. If actual inflation is higher than anticipated inflation then the contractor tries to finish project quickly by employing more resources to the project.

ii. If actual inflation is same as anticipated inflation then project runs smoothly as expected and health of the project would be good.

iii. If actual inflation is lesser than anticipated, then contractor would get benefit from the lesser inflation.

By considering above points, it may be proposed to remove as price escalation clause so that contractor will start taking risk. Above condition is suitable when the government starts their projects on time so that bid would not get obsolete, government pays the running bills in fast tract basis in order to maintain working capital of contractor, government maintains the same policies wherever it affects prices of construction materials.

\subsection{Delay in planned activity}

A construction delay is anything that obstructs the ability of a contractor to maintain a schedule. From the questionnaire survey, it was ranked second overall in cost overrun factors. Evidences showed that projects went to cost overrun when it suffered from delay. Any schedule delay makes the initial cost estimates outdated as price escalation of material bound to happen. Thus, it resulted into cost overruns. Generally, construction delay has occurred from any of the construction team members such as client, consultant and contractor as shown in figure 3. Significant factors affecting delay are nontimely payment to contractor, design revision, not providing drawing on time, poor site management and supervision, etc.

Factor responsible for delay is given in figure 3. Reasons for the each factor could be inflation and political interference, non-timely payment to the contractor, changes in clients requirement, etc. as shown in figure 3 . To prevent delays, solution is proposed as follows:

i. Client should freeze his requirement in initial phase of project in order to prevent frequent changes in design.

ii. Contractor should give managerial training for staff so as to improve efficiency of managerial and supervisory staff.

iii. Designer should increase staff to provide drawing on times.

iv. Government should try to control inflation.

\subsection{Lack of co-ordination between construction parties}

Lack of co-ordination between construction parties might be the reason for the cost overrun due to gap in communication present among client, contractor and consultant. There are various problems observed due to communication 


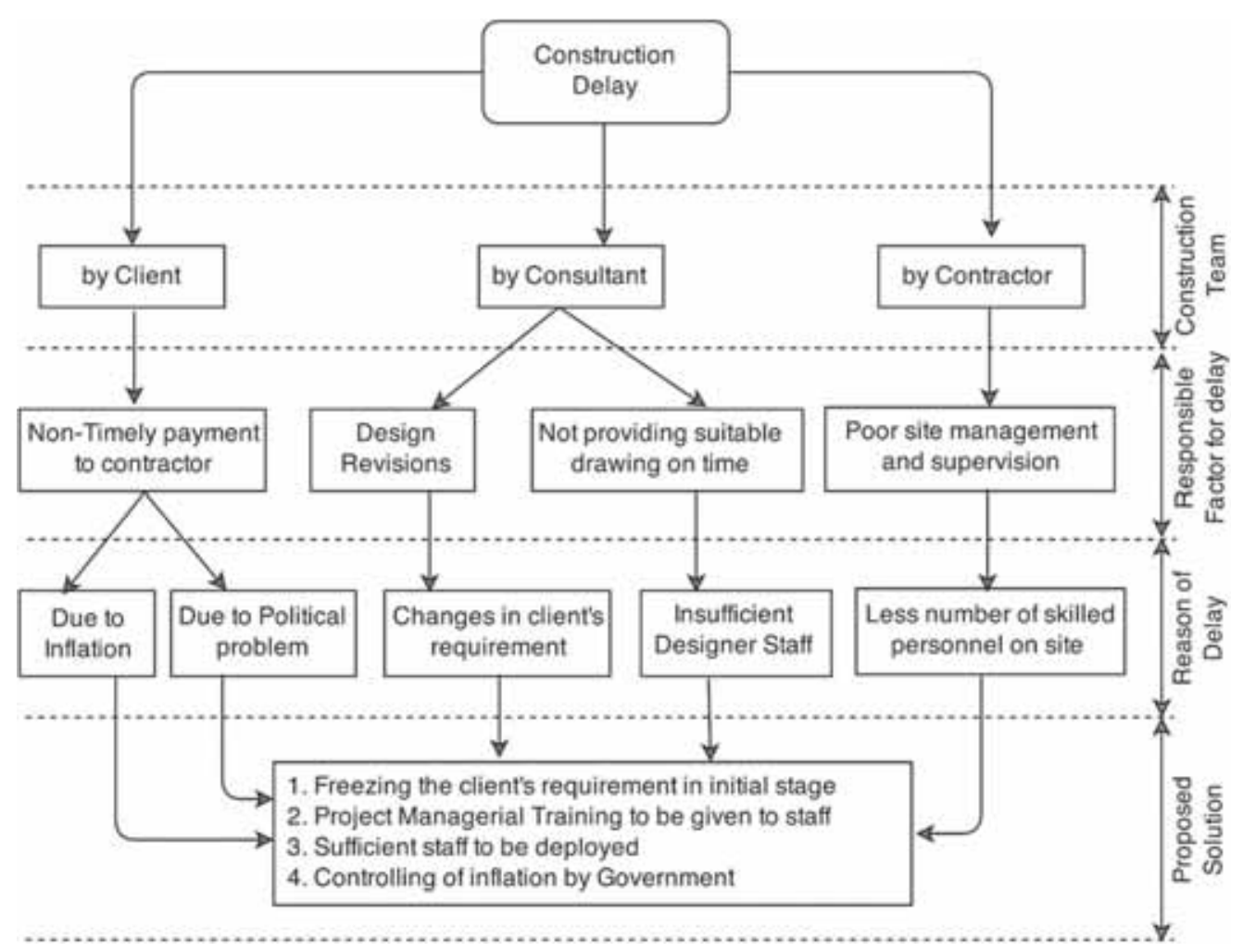

Figure 3. Framework to mitigate delay in planned activity.

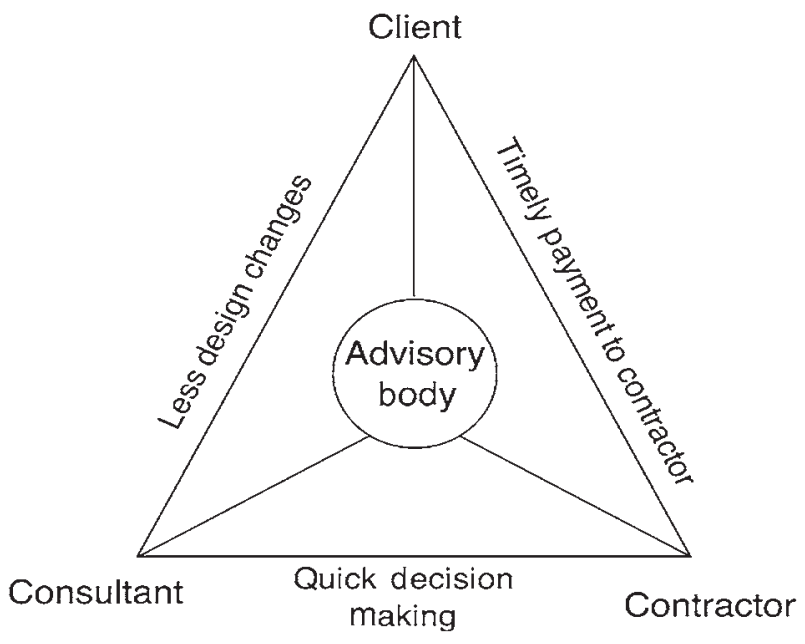

Figure 4. Proposed solution to overcome lack of co-ordination between construction parties.

gap such as frequent changes in design occurs due to gap present between client and consultant, delay in decision making due to gap present between consultant and contractor and non-timely payment to contractor due to gap present between client and contractor.

To overcome these three problems, one additional body is suggested in this framework which called as 'advisory body' as shown in figure 4. Advisory body would help client and consultant for freezing specification and fixing the requirement so that less design changes. Advisory body would also play role between client and contractors by releasing quick bills and removing disputes on bills related issues. Hence, it may be proposed to have an additional body which connects client, consultant and contractor to take care of problems stated above.

\section{Conclusions}

Following conclusions could be drawn based on study:

i. From the opinion of responded across India, it could be concluded that the top three factors affecting cost overruns are price escalation of raw material, delay in planning activity and lack of co-ordination among construction parties. The opinion on these factors was found as similar and important across India as it was verified using ANOVA method.

ii. The questionnaire survey for cost overrun is applicable for all the regions of India as there were no significant differences among construction professionals working across India.

iii. Three components client control component, project management component, and contractor control component were extracted using factor analysis. 
iv. The suggestive framework for price escalation of raw materials, delay in planning activities and lack of coordination among parties, which is given in figure 2 , figure 3, and figure 4 could be useful for planning of new project in the construction.

v. It is suggested in figure 2 to remove price escalation clause from the contact document as most of the professionals have the opinion that major cause of cost overrun was price escalation and if it is removed from the tender document that might have saved the project from the cost overruns.

vi. Based upon figure to figure 3 , it was suggested that client should freeze his requirement in the initial stage, sufficient staff should be deployed and managerial training to be given to his staff to improve on second important factor as delay in planned activities.

vii. In figure 4, it was suggested to deploy a new body called as 'advisory body' which acts as a client's representative which would helps to reduce a communication gap among the parties in construction work.

\section{References}

[1] Avotos I 1983 Cost-relevance analysis for overrun control. Int. J. Project Manag. 1(3): 142-148. Available at: http:// www.sciencedirect.com/science/article/pii/ 0263786383900182 [Accessed January 14, 2016]

[2] MOSPI 2014 Infrastructure Statistics

[3] Durdyev S, Ismail S and Bakar N A 2012 Factors causing cost overruns in construction of residential projects: Case study of Turkey. Int. J. Sci. Manag. 1(1): 3-12

[4] KPMG 2013 Study on project schedule and cost overruns. PMI-KPMG

[5] Frimpong Y, Oluwoye J and Crawford L 2003 Causes of delay and cost overruns in construction of groundwater projects in a developing countries; Ghana as a case study. Int. J. Project Manag. 21: 321-326

[6] Kaliba C, Muya M and Mumba K 2009 Cost escalation and schedule delays in road construction projects in Zambia. Int. J. Project Manag. 27: 522-531

[7] Kaming P F et al 1997 Factors influencing construction time and cost overruns on high-rise projects in Indonesia. Constr. Manag. Econom. 15: 83-94

[8] Moura H P, Teixeira J C and Pires B 2007 Dealing with cost and time in the Portuguese Construction Industry

[9] Azhar N, Farooqui R U and Ahmed S M 2008 Cost overrun factors in construction industry of Pakistan. First International Conference on Construction In Developing Countries (ICCIDC-I) "Advancing and Integrating Construction Education, Research \& Practice" August 4-5, 2008, Karachi, Pakistan, pp. 499-508

[10] Azhar N, Farooqui R U and Ahmed S M 2008 Cost Overrun Factors In Construction Industry of Pakistan. Advancing and Integrating Construction Eduction Research \& Practice, (1st
International Conference on Construction in Developing Countries, Karachi, Pakistan).

[11] Abdullah M R, Azis A A A and Rahman I A 2011 Potential effects on large mara construction projects due to construction delay. Int. J. Integrated Eng. (Issue on Civil and Environmental Engineering)

[12] Harisweni 2007 The framework for minimizing construction time and cost overruns in padang and pekanbaru, Indonesia. University of Teknologi Malaysia

[13] Dissanayaka S M and Kumaraswamy M M 1998 Comparing contributors to time and cost performance in building projects. Build. Environ. 34(1): 31-42

[14] Aziz R F 2013 Factors causing cost variation for constructing wastewater projects in Egypt. Alexandria Eng. J. 52: 51-66

[15] Rahman I A, Memon A H and Karim A T A 2013a Relationship between factors of construction resources affecting project cost. Modern Appl. Sci. 7(1): 67-75

[16] Koushki P A, Al-Rashid K and Kartam N 2005 Delays and cost increases in the construction of private residential projects in Kuwait. Constr. Manag. Econom. 23: 285-294

[17] Le-Hoai L, Lee Y D and Lee J Y 2008 Delay and cost overruns in Vietnam large construction projects: A comparison with other selected countries. KSCE J. Civil Eng. 12(6): 367-377

[18] Olawale Y A and Sun M 2010 Cost and time control of construction projects: Inhibiting factors and mitigating measures in practice. Constr. Manag. Econom. 28: 509-526

[19] Kinnear P R and Gray C D 1994 SPSS for windows made simple-release 10. Psychology Press Limited

[20] Norusis 1994 SPSS Advanced Statistics 6.1. Prentice Hall PTR

[21] Kim J and Mueller C W 1978 Factor analysis statistical methods and practical issues. Eric M Usl., SAGE Publication Inc.

[22] Rahman I A, Memon A H and Karim A T A 2013b. Significant factors causing cost overruns in large construction projects in Malaysia. J. Appl. Sci. 13(2): 286-293

[23] Eshofonie B and Patience F 2008 Factors affecting cost of construction in Nigeria presented to the department of building university of Lagos Akoka, Lagos in partial fufilment of the requirements for the award of masters in construction management

[24] Ameh O J, Soyingbe A A and Odusami K T 2010 Significant factors causing cost overruns in telecommunication projects in Nigeria. J. Constr. Develop. Countries 15(2): 49-67

[25] Sharma S and Goyal P K 2014 Cost overrun factors and project cost risk assessment in construction industry-A state of the art review. Int. Acad. Sci. Eng. Technol. ISSN(P): 2

[26] Omoregie A and Radford D Infrastructure delays and cost escalation: Causes and effects in Nigeria

[27] Rosenfeld Y 2014 Root-cause analysis of construction-cost overruns. J. Constr. Eng. Manag. (DOI:10.1061/ (ASCE)CO.1943-7862.0000789. (C) 2013 American Society of Civil Engineers.)

[28] Mansfield N, Ugwu O and Doran T 1994 Causes of delay and cost overruns in Nigerian construction projects. Int. J. Project Manag. 12(4): 254-260

[29] Doloi H 2013 Cost overruns and failure in project management: Understanding the roles of key stakeholders in construction projects. J. Constr. Eng. Manag. DOI:10.10(C) 2013 American Society of Civil Engineers. CE) 
[30] Cheng Y-M 2014 An exploration into cost-influencing factors on construction projects. Int. J. Project Manag. 32: 850-860.

[31] Shanmugapriya S and Subramanian K 2013 Investigation of significant factors influencing time and cost overruns in
Indian Construction Projects. Int. J. Emerging Technol. Adv. Eng. www.ijetae.com. ISO Certified Journal, 9001(10)

[32] Okpala D C and Aniekwu A N 1988 Causes of high costs of construction in Nigeria. J. Constr. Eng. Manag. 114: 233-244 